\title{
Environmental tourism in Crimea: experience in implementing the sustainable development principles
}

\author{
Irina M. Yakovenko, Svetlana Yu. Tsohla, Anna I. Karlova*, Leonid S. Karlov \\ V.I. Vernadsky Crimean Federal University, Vernadsky av., 4, Simferopol, Russia
}

\begin{abstract}
The conceptual basis of modern changes in tourism is a sustainable development, the basic principles of which are most translated into the idea of ecological tourism. The paper presents the results of a study of the organization of ecological tourist routes and programs in protected areas of the Crimean peninsula. Spatial differences in the density of ecological route network, the functional structure of routes and trails, the degree of their infrastructure and information support were revealed. Attractiveness of the routes is dueto the high concentration of socially significant objects of natural and cultural heritage within boundaries of protected areas. For ecological tourism, the most developed are mountain-forest and coastal areas located in the south-west, south and south-east of Crimea. The implementation heterogeneity on the principles of environmental, economic and social sustainability in regional ecotourism development was established. Violations of the regulation principles of recreational load on natural complexes, preservation and reproduction of the resource quality, insufficient use of potential of local communities in the management system of ecological tourism were revealed. Constructive suggestions for optimizing ecotourism in Crimea on the sustainability principles were formulated.
\end{abstract}

\section{Introduction}

The paradigm of modern tourism provides for the transition to sustainable development, which is understood as achieving a certain balance, mutual alignment, coordination and unity of priority goals of the three main areas of tourist process - social, economic and environmental. The sustainable development principles are implemented in varying degrees in many types and forms of tourism, but the ideas of relations harmonization in the system "tourist - environment" are embodied in ecological tourism as fully as possible. The ecologization process of world tourist movement manifested itself in formation and rapid

\footnotetext{
* Corresponding author: a.karlova@mail.ru
} 
growth of a special segment of the tourist market, as well as in the use of ecotourism as an effective tool for sustainable territorial development at different levels of the spatial hierarchy - global, regional and local. Justification of strategic decisions in the field of organization and management of ecological tourism in specially protected natural areas (SPNA) of the Russian Federation needs the study of successful practices of sustainable development and identification of current problems in different regions of the country (The Strategy for the development of tourism in Russia Federation, 2019).

Analysis of scientific and methodological publications allows to state that there are a number of unresolved issues in the theory and practice of implementing the sustainable development principles in the system of national and regional ecological tourism. The two most important aspects of this problem are considered below.

\subsection{Nonuniformity in implementation of the sustainable development principles in ecological tourism}

H. Ceballos-Lascurain, who first used the term "ecological tourism", considered it as a combination of travel with an environmentally sensitive attitude toward nature, allowing to combine the joy of exploring and learning about specimens of flora and fauna with the opportunity to promote their protection (Ceballos-Lascurain, 1996). The principle of preserving natural and cultural heritage and maintaining basic ecological processes is recognized as central in the ecotourism management. Despite the further development of the sustainable development principles in a number of policy documents of forums (World Ecotourism Summit, 2002), the ecotourism practice is not fully implemented the principles of economic and social impact of tourism on local communities, including the principle of promoting the local people's welfare, the principle of cultural values and traditions, the authenticity of local culture, the principle of harmonization of relations between tourists and local residents.

\subsection{Insufficient status of approaches and mechanisms of sustainable development in ecological tourism}

The concept of sustainable tourism development runs into difficulties of lack of appropriate tools to implement the principle of balancing the economic, social and environmental goals of stakeholders. Many techniques of ecologization of tourist activity use as the main approach to provide the optimal level of territory throughput. Meanwhile, the criteria for assessing the tourist territory capacity and throughput (destination, local object) is not systematized, there is no unity in understanding the content of regulatory and legal support, organizational and economic management mechanisms for sustainable development of ecological tourism. The arsenal of frequently used techniques presents demarketing, tourist fees and fines, environmental certification, codes of tourist behavior, etc.

The following questions were considered in the study process:

- What is the ecotourism's role in implementing the sustainable development principles?

- What is the scale and direction of the ecological tourism development in specially protected natural areas of Crimea?

- What are the level and problems of implementation of sustainability principles in ecological tourism

of Crimea?

- What are the key directions of ecotourism sustainable development in Crimea? 
The study goal - to develop proposals on optimizing the functional, territorial and management structure of ecotourism in Crimea on sustainability principles based on the study results.

\section{Materials and Methods}

The study is based on an analysis of official statistics of the World Tourism Organization, Ministry of Resorts and Tourism of the Republic of Crimea, on the use of provisions of federal legislative acts and state development strategies, materials of scientists' published works, including posted on the Internet.

Within this study, the authors used literary and analytical, comparative and geographical techniques of scientific research and the technique of expert evaluations.

\section{Results and Discussion}

\subsection{Systematization of ideas about the sustainable development principles in ecological tourism}

Analysis of domestic and foreign publications demonstrated the lack of a universal definition of the sustainable development principles of tourism in relation to its ecological variety. Ecotourism is one of the fastest growing segments of world tourism (annual growth of 10 to 15\%) (Selkani, 2020). Most authors link the conceptual model of ecological tourism with integrated activities in protected areas, providing the relationship and interdependence of environmental, recreational and socio-cultural functions of the territory. At the same time, the high variability of ecological tourism models is determined by the formation specifics of network of protected areas in a particular country, differences in the landscape structure, national traditions of nature management, mechanism of state tourism policy, other conditions and factors.

A number of basic tourism development principles in protected areas were formulated by A. V. Drozdov: compliance with basics of reserve management and studies; regulation of tourist flows; reliance on regional attractions, taking into account the buffer zones and adjacent areas; connection with scientific and environmental education structures, specialized tour operators and travel agents; secondary economic function in relation to environmental and social functions; profitability of object (Drozdov, 1998). Individual representatives of environmental movements reject the very idea of developing ecological tourism in protected areas as contrary to the functions of protection and science and allow only excursion activities in the museums of nature reserves (Borejko, 2010).

Approaches to the implementation of conservation function in the ecological tourism development on protected areas have been tested in many national parks and are reflected in numerous recommended practices and guidelines on planning and management (Eagles, McCool, \& Haynes, 2006, Carvace-Franco et all, 2018). The functional zoning of national parks (including the establishment of zones of strict protection of natural biocenoses, protection of cultural heritage sites, recreational areas, economic zones, buffer zones, and others), as well as the rational routing of ecological trails, are generally recognized as methods of ensuring the symbiosis between nature conservation and tourism.

In recent years, interest in problems of ecotourism within the context of implementation of the sustainable development principle of regions and the growth of life quality of local communities is increasing (Çakir et all, 2018, Kummitha, 2020, Mathew \& Sreejesh, 2017, Joshi. \& Sharma, 2020). The areas of implementation of such a sustainability principle as involvement of the local community in planning and management of tourism in the region, 
as well as ways to achieve socio-cultural and psychological balance in the system "tourists - local population" are controversial issues.

The result of using the literary and analytical method was the author's systematization of the sustainable development principles of ecological tourism (Table 1).

Table 1. Sustainable development principles in ecological tourism

\begin{tabular}{|c|c|c|}
\hline $\begin{array}{l}\text { Environmental sustainability } \\
\text { principles }\end{array}$ & $\begin{array}{c}\text { Economic sustainability } \\
\text { principles }\end{array}$ & $\begin{array}{c}\text { Social sustainability } \\
\text { principles }\end{array}$ \\
\hline $\begin{array}{l}-\quad \text { Basement on poorly } \\
\text { altered natural sites and } \\
\text { territories. } \\
-\quad \text { Absence or minimization } \\
\text { of damage from tourism to } \\
\text { the environment and basic } \\
\text { ecological processes. } \\
-\quad \text { Preserving the quality of } \\
\text { natural and cultural resources } \\
\text { for future generations. } \\
-\quad \text { Focus on environmental } \\
\text { education and enlightenment. } \\
-\quad \text { Consideration of mutual } \\
\text { interests of natural } \\
\text { management subjects and } \\
\text { prevention of conflicts } \\
\text { between them. }\end{array}$ & $\begin{array}{l}-\quad \text { Economic } \\
\text { efficiency of the functioning } \\
\text { of ecological tourism } \\
\text { facilities. } \\
-\quad \text { Promoting } \\
\text { quality employment and a } \\
\text { high level of well-being of } \\
\text { local population through } \\
\text { additional economic activity. } \\
-\quad \text { Involvement of local } \\
\text { communities in planning, } \\
\text { decision-making, and } \\
\text { management. } \\
-\quad \text { Compensation at the } \\
\text { expense of profits for } \\
\text { maintenance of ecological } \\
\text { balance and development of } \\
\text { environmental infrastructure. }\end{array}$ & $\begin{array}{l}-\quad \text { Preservation of } \\
\text { authentic sociocultural } \\
\text { environment. } \\
-\quad \text { Support for } \\
\text { cultural values and traditions } \\
\text { of local ethnic groups. } \\
-\quad \text { Providing a } \\
\text { positive experience of } \\
\text { interaction between tourists } \\
\text { and local population. } \\
-\quad \text { Informational and } \\
\text { educational training for local } \\
\text { population. } \\
-\quad \quad \text { Making } \\
\text { ecotourism services } \\
\text { accessible to domestic } \\
\text { tourists and people with } \\
\text { special needs. }\end{array}$ \\
\hline
\end{tabular}

\subsection{Special study methods of ecological tourism problems in the region}

To study the level and problems of sustainability principle implementation in the ecological tourism of Crimea, information resources of the Ministry of Resorts and Tourism of the Republic of Crimea, characterizing the state of the route network of ecological tourism in specially protected natural areas of the region were used (Ministry of Resorts and Tourism, 2018). The ecological tourism structure in each network site was determined by the proportion of routes of different types, including active extreme tours, environmental marine routes, environmental walking routes, environmental horseback riding routes, environmental biking routes, sightseeing and environmental routes, environmental trails, environmental education routes. This allowed us to establish a certain specialization of protected areas and identify disparities in the proposed tourist programs of ecological orientation.

Within the comparative geographical method, the network density of ecological routes of the nature protection system of the Republic of Crimea was calculated. The routes density was defined as the ratio of total length of ecological routes and trails of all types to the area of the protected natural object $\left(\mathrm{km} / \mathrm{km}^{2}\right)$. Based on this calculated indicator and the use of data on the degree of infrastructure and information support eco-routes, studied 29 SPNAs of Crimea were ranked by development degree for ecological tourism.

Traditional indicators for assessing the tourism development scale are the size of tourist flow (number of participants in this type of tourism) and indicators of financial and economic results (income, profit, revenues to the budget, etc.). In this study, an objective difficulty for quantitative analysis was the lack of representative official information in relevant ministries and agencies. Statistical reporting on the number of tourists and the amount of revenue of specially protected natural areas from ecological tourism was conducted by the Ministry of Ecology and Natural Resources of the Republic of Crimea until 2016. Information on 
frequency of visits to the most attractive natural and cultural sites located within the boundaries of regional SPNAs were obtained in the course of expert evaluations and authors' personal field observations.

\subsection{The organizational experience of ecological tourism in the protected natural areas of the Republic of Crimea}

The ecological tourism in the Republic of Crimea develops in the form of ecological routes and trails on the basis of 29 specially protected natural areas. In 2019, 79 routes with a total length of $303.4 \mathrm{~km}$, the structure of which was dominated by ecological walking routes (Figure 1), operated. The number of ecoroutes has a positive dynamics: in 2015, there were only 15 , in recent years a number of horse, bicycle and sea routes were organized. The state nature reserves Novy Svet, Bolshoy kanyon Kryma, the Kazantip nature reserve and a number of local natural monuments, among which the Ak-Kaya mountain stand out, and 4 ecological equestrian routes are organized in the vicinity of which (Table 2), have a high degree of ecoroute network density. A special feature of the Crimean protected territories is the high concentration of

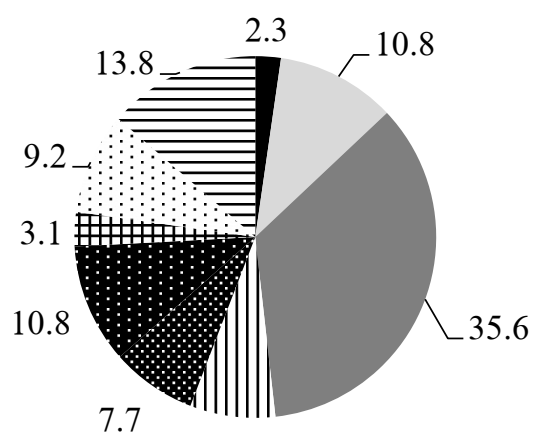

7.7
Active extreme routes

Ecological sea routes

Ecological walking routes

II Ecological equestrian routes

Ecological cycling routes

Excursion and ecological routes

\# Ecological trails

Fig. 1. Structure of ecotourism routes in the Republic of Crimea (\%) (Ministry of Resorts and Tourism of the Republic of Crimea, 2019)

attractions of natural and cultural heritage, which determines the steady flow of tourists in the period from April to November. According to our observations, the most popular ecological routs in Crimea are those in the southeastern mountainous and seaside areas of the peninsula - Golitsynskaya Tropa in Novy Svet and Bolshoy Karadag in the reserve of the same name, as well as the trail opened in 2017. Bolshaya Sevastopolskaya Tropa, a length of $137 \mathrm{~km}$ on the territory of the federal city of Sevastopol. A factor inhibiting the development of ecological tourism, is a high fire danger in the Crimean forests, in the summer season, many destinations are closed to visitors.

Serving the needs of participants in ecological tours on SPNAs of the Republic of Crimea and the city of Sevastopol (guide services, accommodation, cuisine, transportation, sale of souvenirs), according to our estimates, provides additional income for residents of more than 20 rural settlements of the peninsula. For example, in the village of Generalskoye, local residents use more than 30 off-road vehicles to organize trips to the Jur-Jur waterfall and Karabi-Yayla (Yakovenko \& Voronina, 2016). 


\subsection{The problems of implementing the sustainability principles in ecological tourism in Crimea}

The principles of ecological tourism, ensuring environmental sustainability of the natural environment, in Crimea are not fully taken into account. An increase in spontaneous tourist visits is noted in many protected areas of Crimea, forest biocenoses suffer from inordinate horseback tourism and jeeping. Forest fires have become more frequent, for example, the average annual number of fires in the Yalta Nature Reserve reaches 40-50. The optimal recreational capacity of the Crimean forest landscapes should not exceed 300 thousand people per year, with a standard of 1 person per hectare (Sharafutdinov et all, 2017), but the actual load on many popular sites (Grand Canyon, Uchan-Su waterfall, Demerdzhi Mountain, New World tract) in high season can reach 900-1,200 people per day.

The infrastructure of ecoroutes is in poor status. Only $30 \%$ of routes and trails are provided with special markings; no more than $25 \%$ of routes are equipped with benches

Table 2. System of ecological routes of the Republic of Crimea, 2019

\begin{tabular}{|c|c|c|c|}
\hline Specially protected natural areas & $\begin{array}{l}\text { Number of } \\
\text { routes }\end{array}$ & $\begin{array}{l}\text { Route } \\
\text { length, km }\end{array}$ & $\begin{array}{l}\text { Route } \\
\text { density, } \\
\mathrm{km} / \mathrm{sq} \text {. } \\
\mathrm{Km}\end{array}$ \\
\hline \multirow{26}{*}{$\begin{array}{l}\text { Yalta Mountain and Forest Nature Reserve } \\
\text { State Nature Reserve "Haphalsky" } \\
\text { Demerdzhi Yayla State Nature Reserve } \\
\text { State Nature Reserve "Ayu-Dag" } \\
\text { Novy Svet State Nature Reserve } \\
\text { Natural monument "Meganom Peninsula" } \\
\text { Karadag Nature Reserve } \\
\text { Uzun-Syrt Nature Park } \\
\text { State Nature Reserve "Tepe-Oba Mountain Range" } \\
\text { Landscape and recreational park "Fox Bay-Echki- } \\
\text { Dag" } \\
\text { Landscape and recreational park "Quiet Bay" } \\
\text { Natural landscape reserve "Grand Canyon of Crimea" } \\
\text { Nature monument "Tepe-Kermen" } \\
\text { Bakla Nature Monument } \\
\text { Mangup Nature Monument } \\
\text { Nature monument "Belbek Canyon" } \\
\text { Nature monument "Mount Ak-Kaya" } \\
\text { Kazantipsky Nature Reserve } \\
\text { Karalarsky Nature Park } \\
\text { Nature Reserve "Lake Chokrak" } \\
\text { Cape Takil Landscape and Recreation Park } \\
\text { Opuksky Nature Reserve } \\
\text { State Nature Reserve "Dolgorukovskaya Yayla" } \\
\text { Crying Rock State Nature Reserve } \\
\text { Landscape and recreational park "Kizil-Koba" } \\
\text { Tarkhankutsky Nature Park, Atlesh Landscape and } \\
\text { Recreation Park, Dzhangulskoye Landslide Coast } \\
\text { Nature Reserve }\end{array}$} & 10 & 31.5 & 0.22 \\
\hline & 1 & 1.1 & 0.44 \\
\hline & 4 & 15.6 & 0.75 \\
\hline & 2 & 6.8 & 0.30 \\
\hline & 2 & 7.2 & 1.52 \\
\hline & 1 & 2.65 & 0.41 \\
\hline & 2 & 8.5 & 0.29 \\
\hline & 1 & 6.41 & 0.76 \\
\hline & 2 & 5.2 & 0.43 \\
\hline & 2 & 4.1 & 0.26 \\
\hline & 4 & 11.08 & 0.73 \\
\hline & 1 & 6.0 & 2.0 \\
\hline & 1 & 1.0 & 20.0 \\
\hline & 1 & 0.66 & 13.2 \\
\hline & 1 & 2.27 & 2.52 \\
\hline & 1 & 0.47 & 0.47 \\
\hline & 4 & 19.08 & 63.6 \\
\hline & 3 & 17.9 & 3.97 \\
\hline & 3 & 31.24 & 0.46 \\
\hline & 1 & 6.0 & 0.59 \\
\hline & 1 & 1.7 & 0.32 \\
\hline & 23 & 22.5 & 1.41 \\
\hline & 3 & 36.66 & 1.72 \\
\hline & 1 & 0.6 & 2.72 \\
\hline & 2 & 2.68 & 2.63 \\
\hline & 4 & 80.5 & 0.71 \\
\hline
\end{tabular}

gazebos, trash garbage cans, sanitary areas; more than $30 \%$ of eco-trails do not have information panels and stands.

The economic sustainability of ecological tourism in protected natural areas of Crimea is not supported by revenues from the service of tourists: the fee for a visit is introduced only on 16 routes of 79 and includes the cost of excursions in the reserves and equipped caves. 
The experts' survey assessed the involvement degree of the local population of Crimea in the ecotourism service as relatively low; the maximum activity in provision of food and transportation is provided by the villagers of Bakhchisarai District, as well as the population of the federal city of Sevastopol, living in Bolshaya Sevastopolskaya Tropa and the Baidar Valley. Cases of participation of public organizations in the regions of Crimea in the ecotourism management are so far isolated. Among the ethnic groups living in Crimea, representatives of the Crimean Tatar ethnos demonstrate certain success in maintaining cultural traditions, folklore and crafts.

In 2020, an agreement on the development of ecotourism between the Ministry of Resorts and Tourism of the Republic of Crimea and the joint directorate of specially protected natural areas "Zapovedny Krym" was signed. Combining the efforts of the two agencies will help to create conditions for a successful combination of environmental and tourist-recreational movements in the region, the popularization and promotion of environmental tourism programs in the information space.

\section{Conclusion}

The study conducted by the authors revealed a number of problems in the development of ecotourism in

Crimea and made it possible to formulate several recommendations to optimize this area on the principles of sustainability:

- improving the structure of the network of protected areas, including increasing the number and area of national parks;

- conducting a clear functional zoning of protected areas, optimization of the territorial structure of ecological routes and trails taking into account the sustainability of natural complexes;

- regulation of recreational load using administrative, marketing and economic tools;

- development of standards, codes of conduct for tourists, certification of ecological routes and trails;

- development of a multifunctional route "Bolshaya Tavricheskaya Tropa" with the allocation of areas recommended for ecotourism;

- $\quad$ strengthening environmental education work within tourist programs, creation of visit centers in nature reserves and sanctuaries of the region;

- conducting systematic monitoring of demand for ecotourism services and the extent to which it is satisfied;

- improvement of infrastructure, service and information support on the routes and at the points of destination (creation of eco hotels, observation sites, places to observe wild animals, etc.);

- comprehensive introduction of resource-saving and environmentally friendly technologies (non-traditional energy sources, natural building materials, local organic food, etc.);

- Improving the quality of training of guides and tour guides working on environmental routes;

- attracting residents of settlements adjacent to specially protected natural areas to participate in the ecotourism service;

- using the initiatives of local communities in innovation, investment and management activities in the field of ecotourism;

- developing and implementing the Strategy for the development of ecological tourism in the Republic of Crimea and the city of Sevastopol, taking into account the sustainable development principles; 
- coordination of interested parties' actions - government agencies, tourism business, public organizations, scientific and educational institutions, tourists in solving strategic and operational problems;

- optimizing the activities of ecological tourism associations with the participation of volunteers;

- improving the structure and content of the ecotourism section on the Tourist Portal of the Republic of Crimea, developing and promoting a system of ecotourism brands.

\section{References}

1. V.E. Boreyko, The Trojan Horse of Ecotourism: the death of wilderness (2010)

2. O. Çakir, S. Evren, E. Toren, N. Kozac, GeoJournal of Tourism and Geosites, 21(1), 7 (2018)

3. M. Carvace-Franco, W. Carvace-Franco, R. Arce-Bastodas, J. Proano Moreira, Journal of Advanced Research in Management, 9, 4 (28), 744 (2018)

4. H. Ceballos-Lascurain, Tourism, Ecotourism, and Protected areas (1996)

5. A.V. Drozdov, Proceedings of the Russian Academy of Sciences. Series "Geography", 4, 91 (1998)

6. P. Igls, S. Makkul, K.D. Khejns, Sustainable tourism in protected natural areas. Guide to planning and management (2006)

7. K.K. Joshi, V. Sharma, Journal of Tourism \& Hospitality, 9, 426 (2020)

8. H. Kummitha, GeoJournal of Tourism and Geosites, 29(2), 636 (2020)

9. V.N. Sharafutdinov, I.M. Yakovenko, E.A. Pozachenyuk, E.V. Onishhenko, Crimea: a new vector of development of tourism in Russia (2017)

10. World Ecotourism Summit. Final Report, World Tourism Organization (2002), https://www.gdrc.org/

11. I.M. Yakovenko, A.B. Voronina, Socio-economic geography: History, theory, methods, practice, 304 (2016)

12. P.V. Mathew, S. Sreejesh, Journal of Hospitality and Tourism Management, 31, 83 (2017)

13. Ministry of Resorts and Tourism of the Republic of Crimea. Tourist routes of the Republic of Crimea (routes within the borders of specially protected natural territories of the Republic of Crimea, through the largest "cave cities" and caves of Crimea) (2019), https://mtur.rk.gov.ru/

14. I. Selkani, Journal of Tourism \& Hospitality, 9, 436 (2020)

15. The Strategy for the development of tourism in the Russian Federation until 2035 (approved by the Decree of the Government of the Russian Federation of September 20, 2019. No. 2129-r (2019), https://tourism.gov.ru/ 